\title{
Az „Európa-kép” tartalmi vizsgálata a dualizmus kori középiskolai egyetemes történelemtankönyvekben
}

\author{
MolnáR-KovÁcs ZsófiA
}

\begin{abstract}
Pécsi Tudományegyetem Neveléstudományi Intézet
Az „Európa-kép” szimbolikus, kettős értelmezéssel bíró fogalom. Tágabb értelemben történeti, földrajzi, gazdasági, politikai, kulturális entitás, konstrukció, szúkebb értelemben pedig jelenti/jelentheti a képeken, térképeken megjelenített Európát, az Európáról kialakult nézeteket ${ }^{1}$, melyet jelen tanulmányban a tankönyvkutatás keretein belül, a történelemtankönyvek vonatkozásában közelítünk meg.
\end{abstract}

\section{A KUTATÁSI TÉMA MEGJELÖLÉSE, RELEVANCIÁJA}

A dualizmus kori középiskolai történelemtankönyvek „Európa-kép”-ének vizsgálata több szempontból is indokolt. Az „Európa-kép” átfogó, a 19. század második harmadáig, a magyar közoktatásügy korszerúsítésének megkezdéséig, a magyar polgári iskolaügy alapjainak megteremtéséig visszatekintő feldolgozása a történelemtankönyvek vonatkozásában még nem történt meg. A hazai szakirodalomban az 1990-es évek elejétől jelentek meg az európaiságot, a tankönyvi „Európa-kép”-et vizsgáló, illetve azt fókuszba állító szaktanulmányok, melyek - Szabolcs Ottó 1980-as években végzett vizsgálódásaitól eltekintve (lásd Európa-kutatás, 2006) - mindenekelőtt a rendszerváltás utáni tankönyvek elemzését helyezték előtérbe (lásd például Dárdai, 2002; Fischerné Dárdai, 2011, 2012; Domokos, 2002; M. Császár, 2004).

Mészáros István - ezzel párhuzamosan - az Európaiság, magyarság régi tankönyveinkben címú szakcikkében szintén megfogalmazza a sürgető igényt, mely szerint „az 1945 előtti négy évtized hazai tankönyvtermése már a magyar neveléstörténet részét alkotja. Tárgyilagos, előítéletmentes, alapos tartalmi elemzésük [...] halaszthatatlanul fontos feladat." (Mészáros, 1991. 11. o.) Mindezt az is alátámasztja, hogy „A tankönyvkutatások az utóbbi évek neveléstudományi

\footnotetext{
${ }^{1}$ Az Európáról szóló történetfilozófiai diskurzusok nem képezik jelen vizsgálat tárgyát, ugyanakkor szükséges megemlítenünk, hogy „mind történetileg, mind pedig a jelenben voltak és vannak olyan diskurzusok, amelyek azt érintik vagy járják körül, hogy "micsoda Európa”, hogy szükség lenne „Európára”, illetve mit jelent az „európaiság”." (Horváth, 2009. 112. o.; lásd még Penke, 2000; Mollat du Jourdin, 1996)
} 
vizsgálódásainak sorában egyre hangsúlyosabb módon jelennek meg, utat nyitva ezzel olyan szempont- és összefüggésrendszerek elemzéséhez, illetve újraértelmezéséhez, melyek tovább gazdagíthatják az iskola, a nevelés-oktatás világa történéseinek feltárását." (Gróz, 2005. 199. o.) Az 1990-es évek elejétől a nemzetközi fórumokon is gyakran szentelnek figyelmet az európaiság témakörének, illetve az ezzel kapcsolatos tankönyvkutatásoknak (lásd Dárdai, 2002. 73. o.), ugyanakkor a nemzetközi viszonylatban - a nemzeti, illetve a közös identitás megjelenítése kapcsán - már az 1950-es években a tankönyvek felé fordultak.

A dualizmus időszakára fókuszáló, napjainkig közzétett tankönyvkutatások és publikációk mindenekelőtt a történelemtankönyvek, a népiskolai olvasókönyvek és a pedagógiai szakkönyvek vizsgálatával foglalkoznak. Jelen kutatás szintén e sort gazdagítja. A korszak tankönyveinek elemzését illetően behatóbb vizsgálatokat folytattak: Adamikné Jászó Anna (olvasástanítás-történet), Dombi Alice (19. századi tankönyvek, tankönyvírók), Farkas Mária (olvasókönyvek, népiskolai történelemtankönyvek történelemszemlélete) Gróz Andrea (fegyelemre nevelés kérdése a pedagógiai szakkönyvekben), Méreg Martin (Schultz Imre tankönyvírói munkássága), Molnár-Kovács Zsófia (középiskolai történelemtankönyvek és azok változatai, tankönyvszerzői életutak) és Nóbik Attila (neveléstörténeti tankönyvek Rousseau-képe, kánonképzés). (lásd többek között Adamikné Jászó, 1990; Dombi, 2015; Farkas, 2008; Gróz, 2007; Méreg, 2015; Molnár-Kovács, 2016; Nóbik, 2010) Ugyanakkor a korabeli hazai történelemtankönyvek kapcsán megjelent publikációk és analitikus szemléletet tükröző tankönyvkutatások száma kevésnek mondható.

Ma az európaiság identitásunk meghatározó eleme, fontos tehát tudnunk, hogy ennek a koncepcionális alapjai, (oktatás)történeti gyökerei hova nyúlnak vissza a dualizmus korában és a dualizmus kori tankönyvek tartalmaznake erre vonatkozó utalásokat. E helyütt - e gondolati ív alátámasztására érdemes megemlíteni Gerhard Seewann professzor gondolatait, aki maga is úgy fogalmaz, hogy „A reformkor óta folyik elvi síkú vita Magyarországon a magyar identitásról, illetve arról, hogy hol legyen Magyarország helye Európában és ezzel összefüggésben milyen utat válasszon az ország, illetve a nép a mindenkori politikai-történelmi szituációban." (Seewann, 2009. 101. o.)

\section{A KUTATÁS CÉLJA ÉS A KUTATÓI KÉRDÉSEK}

A vizsgálat célja a dualizmus kori középiskolai történelemtankönyvek „Európakép”-ét meghatározó állandó és változó tendenciák és hangsúlyok feltárása.

A központi kutatói kérdés a következő: Hogyan ábrázolták Európát, az európaiságot a tankönyvek, tehát milyen "Európa-kép” bontakozik ki az elemzés alá vont dualizmus kori magyar középiskolai egyetemes történelemtankönyvekben?

Az ehhez kapcsolódó kutatói kérdések pedig a következők:

1. Milyen arányban jeleníti meg a tankönyvi textus és a tankönyvi illusztrációs bázis Európát, az európai történelmi szálakat a vizsgált fejezetek, alfejezetek tartalmához viszonyítva? 
2. Hogyan határozható meg az „európaiság”, illetve „Európa” fogalma a vizsgálat alá vont dualizmus kori magyar középiskolai egyetemes történelemtankönyvekben (a vizsgált fejezetekben, alfejezetekben)?

3. Változtak-e, s ha igen, mennyiben változtak a vizsgált időszakban az „Európakép"-et befolyásoló tankönyvi tartalmak?

\section{A KUTATÁs MÓDSZEREI}

A vizsgálat elemző egységének elkészítése előtt - ugyanakkor a vizsgálat szerves részeként - a teljesség igényével feltártuk, valamint rendszereztük az „Európakép” és „,tankönyvkutatás” fogalmak kapcsolódási pontjait, vizsgálati lehetőségeit és eredményeit a témáról megjelent szakirodalom alapján. A szakirodalomelemzés főként a hazai szakirodalmi bázisra fókuszált, azonban a nemzetközi (mindenekelőtt európai) kutatások ezredfordulót követően közzétett eredményeire is rápillantottunk.

A szintézis során nyilvánvalóvá vált, hogy a hazai (főként történelem) tankönyvi „Európa-kép”-vizsgálatok, illetve azok publikálása a 20. század végén, az 1990-es évektől került az érdeklődés homlokterébe. A számba vett vizsgálati eredmények mindegyike felhívta a figyelmet az Európa-definíció tankönyvi hiátusára. Emellett a sokrétú kutatói törekvések láttatni engedték a téma vizsgálatának módszertani lehetőségeit, elemzési tapasztalatait, ezáltal pedig - közvetett módon - különböző opciókat kínáltak fel a témakör további kutatásához. A nemzetközi kutatói színtér gazdag bázisából merítkező „Európa-kép”-vizsgálatok tágabb perspektívába helyezték a hazai kutatások kézzelfogható eredményeit, ezáltal meghatározó szerepet játszanak/játszhatnak a jövőbeli kutatói irányvonalak tudatos(abb) kijelölésében is. (erről bővebben lásd Molnár-Kovács, 2014)

A dualizmus kori magyar középiskolai egyetemes történelemtankönyvek „Európa-kép”-ét a tartalomelemzés módszerével vettük közelebbről szemügyre. Ennek oka, hogy „a tartalomelemzés egy olyan interdiszciplináris módszer, amelynek segítségével a közlemények (gyakorlatilag a legtöbbször szövegek) rejtett, tehát nyíltan, expressis verbis ki nem fejezett tulajdonságai is feltárhatóak." (Antal, 1976. 44-45. o.)

Így a manifeszt tankönyvi európaiság mellett a látens tartalom is megismerhető (lásd Babbie, 2008. 357-358. o.). A II. világháborút követően előtérbe kerülő metódus alkalmazása a tankönyvek vonatkozásában sem újkeletú, s - ahogy Szabolcs Éva is rávilágít - „Pedagógiai alkalmazása kezdetben azt jelentette, hogy a tankönyvekben tetten érhető értékválasztásokat igyekeztek kimutatni a segítségével." (Szabolcs, 2004. 331. o.).

\section{A KUTATÁS FORRÁSAI}

A kutatás elsődleges forrásait a magyar dualizmus kori középiskolai egyetemes történelemtankönyvek egy sajátos csoportja jelenti: a VII. osztály számára készített 15 db történelemtankönyv, illetve annak 1815 utáni fejezetei, alfejezetei. E tankönyvek 
az újkor történelmének 1648-tól a ,jelenkorig” tartó időszakát tárgyalják. Az 1815 utáni világtörténelmet taglaló tankönyvi részek kezdő kronológiai éve azonos (1815), ugyanakkor az említett vagy ábrázolt utolsó (záró) kronológiai adat (év) a vizsgálat alá vont tankönyvek különböző kiadásainak előrehaladtával párhuzamosan halad időrendben előre.

Ebből (is) kifolyólag az 1815 utáni fejezetek, alfejezetek kiválasztása és vizsgálata lehetővé teszi a dualizmus kori középiskolai történelemtankönyvekben tárgyalt vagy ábrázolt ,,jelenkor” „Európa-kép”-ének változó és állandó tendenciáit megragadó fejlődési ív megrajzolását.

A vizsgálat során reprezentatív elemzés megvalósítására törekedtünk, ennek érdekében pedig az alábbi kitételek mentén határoztuk meg a tankönyvek kiválasztásának kritériumait:

- középiskolai (gimnáziumi és reáliskolai) tankönyvek vizsgálata,

- egyetemes történelemtankönyvek vizsgálata,

- VII. osztály számára készített tankönyvek vizsgálata,

- minden rendelkezésre álló kiadás vizsgálata,

- segédkönyvek vizsgálatától való eltekintés.

A vizsgálat tehát e paraméterek mentén összesen 15 darab tankönyv elemző áttekintését valósította meg, melyek szerzőinek nevét, a kiadás évét és a tankönyv címét e helyütt is megadjuk: ${ }^{2}$

1. Mangold Lajos (1885): Világtörténelem. (a továbbiakban: Mangold, 1885)

2. Mangold Lajos (1891): Világtörténelem. (a továbbiakban: Mangold, 1891)

3. Mangold Lajos (1902): Világtörténelem. (a továbbiakban: Mangold, 1902)

4. Márki Sándor (1903): Egyetemes történelem. (a továbbiakban: Márki, 1903)

5. Mika Sándor (1904): Világtörténet. (a továbbiakban: Mika, 1904)

6. Mika Sándor (1912): Világtörténet. (a továbbiakban: Mika, 1912)

7. Sebestyén Gyula (1906): Egyetemes történet. (a továbbiakban: Sebestyén, 1906)

8. Szigethy Lajos (1903): Egyetemes történet. (a továbbiakban: Szigethy, 1903)

9. Szölgyémy János (1914): Világtörténet. (a továbbiakban: Szölgyémy, 1914)

10. Ujházy László (1904): Egyetemes történelem. (a továbbiakban: Ujházy, 1904)

11. Ujházy László (1913): Egyetemes történelem. (a továbbiakban: Ujházy, 1913)

12. Varga Ottó (1904): Világtörténet. (a továbbiakban: Varga, 1904)

13. Vaszary Kolos (1904): Világtörténelem. (a továbbiakban: Vaszary, 1904)

14. Vaszary Kolos (1912): Világtörténelem. (a továbbiakban: Vaszary, 1912)

15. Takáts György (1917): Történelem. (a továbbiakban: Takáts, 1917)

E tankönyvek sorában egy leányközépiskolai tankönyv is helyet kapott (lásd a fenti lista 15. tétele), mely a felső leányiskolák, a leánygimnáziumok és a felső kereskedelmi leányiskolák III. osztály számára készült (Takáts, 1917). A leányközépiskolai tankönyv vizsgálata - annak ellenére, hogy az iskolatípus és az évfolyam nem feleltethető meg egy az egyben a fiúközépiskolák esetében

\footnotetext{
${ }^{2}$ A vizsgálat alá vont 15 db történelemtankönyv a budapesti Oktatáskutató és Fejlesztő Intézet Pedagógiai Könyvtár és Múzeum Tankönyvtárában található.
} 
rögzített paramétereknek - összevetési alapot kínált, illetve betekintést engedett a leányközépiskolák dualizmus kori egyetemes történelemtanításába.

A másodlagos forrásokat tekintve lehetőség adódott a hazai tankönyvi „Európa-kép”-vizsgálatok kutatási előzményeinek, szakirodalmi forrásainak teljeskörű elemző áttekintésére, szisztematikus feldolgozására. A hazai tankönyvi szakirodalom - második világháborút követően gyarapodó - sokrétú tematikus csomópontjait áttekintve láthatóvá vált, hogy a magyarországi - mindenekelőtt történelmi tárgyú - tankönyvek „Európa-kép”-ének vizsgálata, szakirodalmi tárgyalása a 20. század végén, a rendszerváltást követően került elötérbe. Az 1990-es évek elejétől fogva a tankönyvi „Európa-kép”-kutatás - a tudományos tankönyvelemzések sajátos szegmenseként - megjelent a magyar tankönyvi szakirodalom egyre szélesebb spektrumot felölelő palettáján.

A hazai kutatások, közzétett vizsgálati eredmények közös vonása mindenekelőtt az Európa-fogalom definiálatlanságának tudatosítása a fókuszba került történelem- és földrajz tankönyvek vonatkozásában. Emellett láthatóvá vált a téma vizsgálatához elengedhetetlen - egymást kiegészítő kvantitatív és kvalitatív módszereket egyaránt alkalmazó - módszertani háttér, mely az eredmények árnyalt értelmezését segíti elő.

A feltárt nemzetközi „Európa-kép”-vizsgálatok egyértelmúvé teszik a magyar kutatói törekvések relevanciáját, a hazai eredmények illeszkedését a nemzetközi trendekbe, egyúttal lehetőséget, igényt és alapot teremtenek a további - tematikusan, térben és időben kiszélesedő - tankönyvvizsgálatok lefolytatásához. (bővebben lásd Molnár-Kovács, 2014)

\section{A TANKÖNYVEK ELEMZÉSE}

Az 1815 utáni fejezetek, illetve alfejezetek az ún. legújabb kor világtörténelmi áttekintésére vállalkoznak, mely mindenekelőtt - a tankönyvi fejezetek, alfejezetek címe alapján - az alkotmányos, nemzeti és szociális küzdelmek tárgyalását helyezi a fókuszba (lásd Mangold, 1885. 188-212. o.; Mangold, 1891. 229-274. o.; Mangold, 1902. 156-205. o.; Márki, 1903. 134-173. o.; Mika, 1904. 124-160. o.; Mika, 1912. 140-180. o.; Sebestyén, 1906. 178-222. o.; Szigethy, 1903. 138-176. o.; Szölgyémy, 1914. 106-139. o.; Ujházy, 1904. 177-235. o.; Ujházy, 1913. 123-167. o.; Varga, 1904. 145-175. o.; Vaszary, 1904. 136-171. o.; Vaszary, 1912. 125-163. o.; Takáts, 1917. 106-120. o.).

A tankönyvek mintegy fele ugyanakkor külön egység keretén belül szót ejt a legújabb kor múvelődéstörténeti viszonyairól (lásd Mangold, 1885. 213-228. o.; Mangold, 1891. 274-277. o.; Mangold, 1902. 205-207. o., 210. o.; Márki, 1903. 173-197. o.; Szölgyémy, 1914. 140-143. o.; Vaszary, 1912. 163-183. o.; Takáts, 1917. 120-121. o.), továbbá a vizsgált kötetek mintegy 3/4-e egy külön fejezetben politikai földrajzi vonásokat is tárgyal (lásd Mangold, 1902. 214-262. o.; Márki, 1903. 198-250. o.; Mika, 1904. 169-248. o.; Mika, 1912. 189-259. o.; Sebestyén, 1906. 223-262. o.; Szigethy, 1903. 180-254. o.; Szölgyémy, 1914. 145-191. o.; Ujházy, 1904. 236-307. o.; Ujházy, 1913. 167-220. o.; Vaszary, 1904. 185-236. 
o.; Vaszary, 1912. 189-232. o.). Jelen vizsgálat során azonban e két egység vizsgálatától eltekintettünk.

A tartalomelemzés előkészítéseként - ugyanakkor egy iránymutató vizsgálati fázisként - a fókuszba emelt tankönyvi fejezetek/alfejezetek oldalait először áttekintettük aszerint, hogy Európa, az Európán kívüli világ, vagy az Európán kívüli világ Európával közös történelmi említését, ábrázolását valósítja-e meg nagyobb oldalszámban, illetve arányban ${ }^{3}$.

A kibontakozó eredmények alapján megállapítható Európa világtörténelmének tankönyvi dominanciája; kiemelkedően nagyarányú önálló ábrázolása a vizsgált tankönyvi fejezetekben egyértelmúen látható. Százalékos megoszlásban mindez azt jelenti, hogy a 15 db tankönyv vizsgálat alá vont (al)fejezeteiben átlag 93 \%-ot tesz ki Európa történelme ${ }^{4}$, mely az egyes kötetekre vetítve 79,5-100 \% közötti tankönyvi reprezentációt jelent.

Az 1815 utáni tankönyvi fejezetek, alfejezetek tartalomelemzésének lépései a következőképpen foglalhatók össze:

1. A kutatói célok és kutatói kérdések alapján a kutatási források és a vizsgálati módszer(ek) meghatározása,

2. Tartalmi főkategóriák körvonalazása és rögzítése; a főkategóriák átfogó kvantitatív elemzése,

3. „Európa” mint tartalmi főkategória részletes vizsgálata; az „Európá”-val kapcsolatos kifejezések, gondolati ívek összegyújtése, rendszerezése,

4. „Európá”-val kapcsolatos szókapcsolatok vizsgálata; hívószavak indukálása,

5. A hívószavak kategorizálása; tartalmi alkategóriák megalkotása,

6. A hívószavakra építve a tartalmi alkategóriák vizsgálata,

7. Összegzés - a vizsgálati eredmények rögzítése az „Európa” mint tartalmi főkategóriára vonatkozóan.

A továbbiakban a 2-7. vizsgálati lépéseket részletesen is feltárjuk, ismertetjük. $\mathrm{Az}$ 1. pontra azonban az alábbiakban nem térünk ki, melynek oka, hogy a kutatói célok, kutatói kérdések, a kutatás forrásai és a vizsgálati módszerek a tanulmány bevezetô részében már bemutatásra kerültek.

\section{TARTALMI FŐKATEGÓRIÁK KÖRVONALAZÁSA ÉS RÖGZÍTÉSE; A FŐKATEGÓRIÁK ÁTFOGÓ KVANTITATÍV ELEMZÉSE}

A tartalmi főkategóriák felállítása során több szempont is mérlegelésre került. Egyrészt figyelembe kellett venni, hogy a meghatározásra kerülő főkategóriák azonos kategóriaszintet képezzenek, tehát ne merüljön fel az alá-fölérendeltségi viszony lehetősége a főkategóriák között. Másrészt pedig az „európaiság”, illetve az „Európa-kép”-vizsgálat aspektusának mélyebb elemzési lehetőségét és

\footnotetext{
${ }^{3}$ Az oldalszámok megállapítása során kerekítést alkalmaztunk. 0-0,4 oldal között 0 oldalra, míg 0,5-1 oldal között 1 oldalra kerekítettük a tankönyvi oldalszámokat.

4 Az Európán kívüli világ átlagban 1,4%-ot, míg az Európán kívüli világ Európával közös említése, ábrázolása 5,6 \%-ot tesz ki a vizsgált tankönyvi egységekben.
} 
igényét előre vetítve „Európa” mint alapveto fokkategória rögzítése kézenfekvő és tulajdonképpen evidens választásnak bizonyult.

Ebből kifolyólag a főkategóriák körvonalazása során a következő öt főkategória került meghatározásra: ${ }^{5}$

1. Európa (Európa, európai, európai-, europai, Európa-, európa-, Europe, Europa, europea, europ., Europäischer)

2. Amerika (Amerika, amerikai, Amerikai, Amerique, amerik, America)

3. Ázsia (Ázsia, ázsiai)

4. Afrika (Afrika, afrikai, sötét földrész)

5. Ausztrália (Ausztrália, ausztráliai, ausztrál, Oczeania)

A főkategóriákat először egy átfogó, valamennyi főkategóriát érintő kvantitatív elemzésnek vetettük alá. Ennek során az öt főkategóriát, illetve az azokat reprezentáló szóösszetételeket, kifejezéseket, előtagokat és rövidítéseket (lásd fentebb, a főkategóriák mögötti zárójeleket) minden egyes vizsgált tankönyvi fejezetben/alfejezetben megszámoltunk, tehát rögzítettük az előfordulások számát.

Az „Európa” főkategóriát ezen túlmenően, további lépésekben - hívószavak és alkategóriák felállítása révén - is vizsgáltuk, míg a többi főkategória („Amerika”, „Ázsia”, ,Afrika” és „Ausztrália”, tehát összefoglalóan az „Európán kívüli világ") mélyebb elemzésétől - a kutatói célokat és a kutatói kérdéseket szem előtt tartva - eltekintettünk. (Az átfogó kvantitatív elemzés eredményeit az 1. táblázat összesíti.)

Az öt főkategóriát a vizsgált 15 db tankönyv 1815 utáni fejezeteiben és alfejezeteiben összesen $727 \mathrm{db}$ kifejezés reprezentálja. Valamennyi tankönyv esetében egyértelmúen megállapítható az „Európa” főkategória előfordulásának dominanciája. A Vaszary Kolos 1912. évi történelemtankönyvéből nyert adatok például jól illusztrálják a teljes mintát - egyesével és összességében is - jellemző arányokat. E tankönyvben a vizsgálat alá volt 1815 utáni tankönyvi egységben „Európa” harmincötször, „Amerika” tízszer, „Ázsia” nyolcszor, „Afrika” háromszor, míg az „Ausztrália” főkategória egyszer jelenik meg (lásd 1. táblázat; lásd még Vaszary, 1912. 125-163. o.).

Ha az összesített eredményeket, tehát az egyes tankönyvi előfordulások összesített adatait áttekintjük, akkor világosan körvonalazódnak a teljes vizsgálati mintát meghatározó átlagszámok és átlagarányok. A 727 db (100\%) főkategória-előforduláson belül a legnagyobb számban és arányban az „Európa” főkategória van jelen $468 \mathrm{db}(64,4$ \%) megjelenéssel. Ezen túlmenően „Amerika” összesen 136 db (18,7 \%), „Ázsia” 65 db (9\%), „Afrika” 44 db (6 \%), „Ausztrália” pedig $14 \mathrm{db}(1,9 \%)$ szóösszetétellel képviseli a további négy főkategóriát (lásd 1. táblázat).

\footnotetext{
${ }^{5}$ A főkategóriák mögött zárójelben, dőlt betűkkel valamennyi, a vizsgált tankönyvi fejezetekben/alfejezetekben szereplő, az adott főkategória elnevezését reprezentáló kifejezést, szóösszetételt, előtagot és rövidítést megadtuk.
} 
1. táblázat. A tartalmi fökategóriák előfordulása a vizsgált tankönyvek 1815 utáni fejezeteiben és alfejezeteiben $(\mathrm{db})$

\begin{tabular}{|l|l|l|l|l|l|l|}
\hline Tankönyvek & \multicolumn{5}{|c|}{ Tartalmi fókategóriák } & Összes \\
& Európa & Amerika & Ázsia & Afrika & $\begin{array}{c}\text { Auszt- } \\
\text { rália }\end{array}$ & \\
\hline Mangold, 1885 & 19 & 7 & 0 & 1 & 0 & 27 \\
\hline Mangold, 1891 & 51 & 10 & 7 & 5 & 0 & 73 \\
\hline Mangold, 1902 & 44 & 9 & 7 & 9 & 3 & 72 \\
\hline Szigethy, 1903 & 47 & 10 & 4 & 1 & 0 & 62 \\
\hline Márki, 1903 & 49 & 29 & 11 & 6 & 3 & 98 \\
\hline Vaszary, 1904 & 29 & 10 & 4 & 1 & 0 & 44 \\
\hline Mika, 1904 & 31 & 10 & 1 & 4 & 2 & 48 \\
\hline Varga, 1904 & 32 & 5 & 4 & 2 & 0 & 43 \\
\hline Ujházy, 1904 & 15 & 6 & 1 & 0 & 1 & 23 \\
\hline Sebestyén, 1906 & 28 & 6 & 4 & 1 & 0 & 39 \\
\hline Mika, 1912 & 28 & 10 & 1 & 4 & 2 & 48 \\
\hline Vaszary, 1912 & 35 & 10 & 8 & 3 & 1 & 57 \\
\hline Ujházy, 1913 & 17 & 5 & 1 & 0 & 1 & 24 \\
\hline Szölgyémy, 1914 & 32 & 9 & 11 & 7 & 1 & 60 \\
\hline Takáts, 1917 & 8 & 0 & 1 & 0 & 0 & 9 \\
\hline Összesen $(\mathrm{db})$ & 468 & 136 & 65 & 44 & 14 & 727 \\
\cline { 2 - 6 }$(\%)$ & 64,4 & 18,7 & 9 & 6 & 1,9 & 100 \\
\hline
\end{tabular}

\section{„EURÓPA" MINT TARTALMI FŐKATEGÓRIA RÉSZLETES VIZSGÁLATA; AZ „EURÓPÁ”-VAL KAPCSOLATOS KIFEJEZÉSEK, GONDOLATI ÍVEK ÖSSZEGYÚJTÉSE, RENDSZEREZÉSE}

A továbbiakban az „Európa” főkategória részletekbe menő elemzésére fókuszálunk. Ahogy fentebb már ismertettük, az „Európa” főkategória esetében is megszámoltuk a vizsgált tankönyvi (al)fejezetekben az azt megjelenítő szóösszetételeket, kifejezéseket, előtagokat és rövidítéseket, mely 468 db előfordulást jelentett. ${ }^{6}$ Ezt követően kvantitatív és kvalitatív irányú, analizáló és szisztematizáló munkafázis egyaránt következett. Ennek szellemében egyrészt figyelmet fordítottuk az „Európa” főkategória előfordulási gyakoriságának meghatározására a vizsgált tankönyvi fejezetekben/alfejezetekben egy ún. sürüségi mutató-

\footnotetext{
6 Ehelyütt meg kell jegyeznünk, hogy a 468 db „Európa” tartalmi főkategória-előfordulás vizsgálata a tankönyvi textust és a tankönyvi illusztrációs bázist egyaránt érintette, ugyanakkor a vizsgált tankönyvi egységekben összesen csupán 3 db grafikus illusztráció található, melyekben szerepel „Európa” (lásd Mangold, 1891. 250-251. o.; Mangold, 1902. 166-167. o.; Szigethy, 1903. 176. o.). Ebből kifolyólag az „Európa-kép” elmélyültebb vizuális elemzése, illetve az Európát ábrázoló képi illusztrációk - eredeti kutatói tervek között szereplő - ikonográfiai/ikonológiai elemzése nem valósul(hatot)t meg. A 3 db grafikus illusztráció a kortani/időrendi táblázatok közé tartozik, melyek a 468 db (100 \%) „Európa” tartalmi főkategória-előfordulás csupán 0,6 \%-át jelenítik meg.
} 
szám ${ }^{7}$ segítségével, másrészt pedig táblázatokba rendezve, idézetek formájában összegyújtöttük azokat a gondolati íveket, tartalmi egységeket, melyekben az „Európa” főkategória megjelenik.

A kvantitatív munkafázis elvégzése során az egyes tankönyvi sûrúségi mutatókat több aspektusból is rendszereztük. Egyrészt csoportosítottuk a súrûség szerinti sorrend, másrészt a tankönyvek kiadási éve szerinti sorrend, harmadrészt pedig a szerzői ábécérend (azon belül pedig a kiadás éve) alapján. A sûrûség szerinti sorrend mentén csoportosított mutatószámok nyilvánvalóvá teszik, hogy a vizsgált tankönyvi egységekben átlagosan minden tankönyvi oldalon egyszer említik Európát, továbbá az 1891-1903 között megjelent tankönyvekben (kivéve: Mangold, 1902) a legnagyobb az „Európa” főkategória tankönyvi sûrûségi mutatója. ${ }^{8}$ Ez utóbbi megállapítást a kiadási év szerinti sorrend is megerősíti. Ugyanakkor a szerzői ábécérend esetében elmondható, hogy a kapott eredmények meglehetősen heterogén képet mutatnak, s a súrúségi mutatók alapján nem körvonalazódnak markáns tendenciák a korabeli tankönyvi „Európa-kép”-ről, annak állandó és változó jegyeiről.

A kvalitatív (előkészítő) munkafázis részeként minden vizsgálat alá vont tankönyvi egység esetében külön táblázatokban rendszereztük az „Európá"-t megjelenítő gondolati íveket (idézeteket). ${ }^{9}$

\section{„EURÓPÁ"-VAL KAPCSOLATOS SZÓKAPCSOLATOK VIZSGÁLATA; HÍVÓSZAVAK INDUKÁLÁSA}

Az előző lépésben ismertetett kvalitatív munkafázis az „Európa” főkategória elmélyültebb vizsgálatát készítette elő. Az „Európá”-val kapcsolatos kifejezések, gondolati ívek összegyújtését követően minden egyes idézet esetében az azokban előforduló, „Európá”-t reprezentáló szókapcsolatokat megvizsgáltunk. E vizsgálat két allépésben történt. Egyrészt minden gondolati ívet, szókapcsolatot áttanulmányoztunk abból a szempontból, hogy azokban megjelenik-e az „európaiság” fogalma, „Európa” konkrét definíciója.

Ennek során megállapítottuk, hogy a vizsgált tankönyvi egységek nem határozzák meg Európa fogalmát, tehát nem tesznek közzé konkrét definíciót Európáról, illetve az európaiságról. Másrészt pedig minden szókapcsolathoz, illetve szóösszetételhez egy-egy hívószót társítottunk. E hívószavak indukálása során igyekeztünk az eredeti szövegkörnyezetben szereplő kifejezést megőrizni, hívószóként is felhasználni, illetve szükség esetén - ha a szövegkörnyezet nem tette lehetővé az eredeti kifejezések hívószóként való alkalmazását, akkor -

\footnotetext{
${ }^{7}$ Mutatószám = egy oldalra jutó „Európa” tartalmi főkategória száma tankönyvenként („Európa” főkategória összesített száma a vizsgált fejezetekben, alfejezetekben / 1815 utáni vizsgált fejezetek, alfejezetek összoldalszáma)

8 A legmagasabb tankönyvi sưrúségi mutatóval Márki Sándor tankönyve (Márki, 1903), míg a legkevesebbel Ujházy László tankönyvi kötete (Ujházy, 1904) rendelkezik. Az első esetében minden 3/4-ed oldalon (tehát egy oldalon legalább egyszer), míg a második esetében minden negyedik oldalon tárgyalják „Európá”-t a tankönyvi (al)fejezetekben.

${ }^{9}$ A táblázatokat azok jelentős terjedelmére tekintettel jelen tanulmányban nem közöljük.
} 
törekedtünk a jelentésben hozzájuk legközelebb eső szavak és kifejezések hívószóként való megadására. Amennyiben egy gondolati ívbe több „Európá”-val kapcsolatos kifejezés is beletartozott, azokat egy idézeten belül tüntettük fel, ugyanakkor mindegyik kifejezéshez külön sorszámot és hívószót társítottunk.

\section{A HívószavaK KATEGorizÁlÁSA; TARTALMi ALKATEGÓRIÁK MEGALKOTÁSA}

A hívószavak rögzítését követően megszámoltuk azokat: összesen 104 db hívószó került meghatározásra az idézetekben fellelhető „Európa” szókapcsolatok tüzetesebb vizsgálata során. A hívószavak megalkotását követően pedig arra törekedtünk, hogy a hívószavakat kategorizáljuk, tehát az „Európa” tartami fókategórián belül olyan tartalmi alkategóriákat állítsunk fel, melyekbe az indukált hívószavak besorolhatóak. A tartalmi alkategóriák konstruálása során tudatosan eltekintettünk attól, hogy a felállításra kerülő alkategóriákhoz körülbelül azonos számú hívószó tartozzon, mert úgy véltük, hogy az egyes alkategóriákat reprezentálni képes hívószavak mennyisége is kifejez(het)i majd a hangsúlyokat. A hívószavak alapos és többszintú áttekintését követően az alábbi öt tartalmi alkategória született:

- Európa mint az államok/nemzetállamok konstrukciója

- Európa mint (belső és külső) eröviszony-alakitó és/vagy -fenntartó konstrukció

- Európa mint egységes egész konstrukció

- Európa mint ipari/kereskedelmi konstrukció

- Európa mint müveltségi/müvelödési konstrukció

A 104 db hívószó pedig az alábbi megoszlásban képviseli az egyes tartalmi alkategóriákat:

- Európa mint az államok/nemzetállamok konstrukciója: 30 db hívószó ${ }^{10}$

- Európa mint (belső és külső) erőviszony-alakitó/-fenntartó konstrukció: $49 \mathrm{db}$ hívószó ${ }^{11}$

- Európa mint egységes egész konstrukció: 8 db hívószó ${ }^{12}$

\footnotetext{
10 abszolút monarchiák, abszolutizmus, alattvalók, alkotmányos fejlődés, alkotmányos uralom, alkotmányosság, államok, birodalom, birtokok, dinasztia állása, Európán kívüli alkotmány, fejedelmek, kormányok, köztársaság, (nagy)hatalmak, nemzetek/népek, Oroszország, országok, parlamentáris alkotmány, tengeri hatalmak, török birodalom, török tartományok, Törökország, udvarok, uralkodók, város, vezető államférfi/miniszter, vezető államok/országok, vezető hatalom, vezető szerep/parancsoló állás

11 beavatkozás, béke, (béke)konferencia, (béke)kongresszus, békés fejlődés, diplomácia, ellenszenv/támogatás hiánya, érdeklődés/figyelem, események, (fegyveres) harc/konfliktus, felkelések, forradalmak, forradalmi eszmék, forradalmi szellem, gyámság, gyarmatállamok, gyarmatbirodalom, gyarmatok, gyarmatosítás, gyarmatosító államok, (háborús/fegyveres) szembenállás, hadi célok/hadi fejlesztés, hadsereg, (hatalmi) befolyás, hatalmi/politikai egyensúly, hegemónia, helyzet(kép), hódítás, jóváhagyás/helybenhagyás, keleti kérdés, kivándorlási mozgalmak, követelések, külkapcsolat, külügyi politika, küzdelmek, legitimáció, mozgalmak, politika, reakció, régi Európa, rokonszenv/támogatás, szabadság mozgalmak, szabadságharc, szociális mozgalmak, szövetségi rendszerek, tekintély fenntartása, terjeszkedés, tisztek, vér nélküli diadal, viszonyok

12 általános áramlat, egész/egység, kontinens, közszellem, minta/mód, terjedelem/méret, (újkori) modern, (újkori) történelmi áttekintés
} 
- Európa mint ipari/kereskedelmi konstrukció: 9 db hívószó ${ }^{13}$

- Európa mint müveltségi/müvelődési konstrukció: 8 db hívószó ${ }^{14}$

\section{A HÍvósZAVAKRA ÉPÍTVE A TARTALMI ALKATEGÓRIÁK VIZSGÁlATA}

A megalkotott öt tartalmi alkategória közül tehát az „Európa mint az államok/nemzetállamok konstrukciója” és az „Európa mint (belsós külső) erőviszonyalakitó/-fenntartó konstrukció" rendelkezik a legnagyobb hívószó bázissal (30, illetve $49 \mathrm{db}$ hívószó). A további három alkategória pedig körülbelül azonos számú $(8,9$, illetve 8 db), az előző kettő alkategóriához képest mintegy negyedét, ötödét kitevő hívószókészlettel bír.

Az alkategória-rendszer felállításának, valamint a hívószavak alkategóriákhoz társításának véglegesítését követően először tankönyvenként, a tartalmi alkategóriák mentén csoportosítottuk a konkrét tankönyvi idézetekhez társított hívószavakat. A hívószavak tankönyvi rendszerezését táblázatok, illetve diagramok segítségével végeztük el, mely lehetőséget teremtett a hívószavak mennyiségi faktorainak többszintú - az „Európa” főkategória és a tartalmi alkategóriák szintjén horizontálisan és vertikálisan egyaránt szisztematizált rögzítésére is.

Ahogy fentebb már utaltunk rá, a 15 db történelemtankönyv vizsgált fejezeteiben/alfejezeteiben összesen $468 \mathrm{db}$ „Európa” főkategória előfordulást („Európá”-t reprezentáló) szóösszetételt, kifejezést, előtagot és rövidítést) azonosítottunk, melyek mindegyikéhez tehát egy-egy hívószót társítottunk. Ezt követően a hívószavak előfordulását a tartalmi alkategóriák mentén, tankönyvenként összesítettük. Ennek során pedig többféle csoportosítási aspektust (kiadás éve, szerzői ábécérend és hívószavak száma szerinti csoportosítás) is figyelembe vettünk, mely néhány kutatói „alapkonzekvencia” érzékeltetésének teret engedett.

Valamennyi tankönyvben egyértelmúen láthatóvá vált az „Európa mint az államok/nemzetállamok konstrukciója” és az „Európa mint (belső és külső) erőviszonyalakító/-fenntartó konstrukció" tartalmi alkategóriák túlsúlya. Az előbbi - tankönyvtől függően - 29,5 \%-tól 58 \%-ig (a leányközépiskolai tankönyvben: 62,5 \%-ban), míg az utóbbi hasonlóképpen 29 \%-tól 50 \%-ig (a leányközépiskolai tankönyvben: 0 \%-ban) jellemzi a vizsgálati mintát. E két tartalmi alkategória tankönyvi előfordulása tehát körülbelül azonos arányú, amit az is bizonyít, hogy hat tankönyv esetében az egyik (lásd Mangold, 1885; Mika, 1904, 1912; Szigethy, 1903; Ujházy, 1904; Takáts, 1917), míg további hat tankönyv esetében (lásd Mangold, 1891, 1902; Márki, 1903; Sebestyén, 1906; Ujházy, 1913; Varga, 1904) a másik alkategória van jelen nagyobb arányban. Három tankönyvi egységben pedig a két alkategória százalékos megjelenése azonos (lásd Szölgyémy, 1914;

\footnotetext{
13 hitelezők, iparcikkek, ipari védekezés, iparos állam, iparos országok, kereskedelem, közlekedés, szállított nyerstermékek, távolsági összeköttetés

14 egyetemek, hagyományok, jogfelfogás, kereszténység, múveltség, oktatók, tanulmányút, társaságok
} 
Vaszary, 1904, 1912). A további három tartalmi alkategóriát tekintve ennél jóval kevesebb százalékos előfordulás jellemző. Az „Európa mint egységes egész konstrukció" 0-20,5 \% között, az „Európa mint ipari/kereskedelmi konstrukció" 0-7,1 \% között, míg az „Európa mint müveltségi/müvelodési konstrukció” 0-8,5 \% között van jelen a tankönyvekben.

A kiadás éve (időrend) szerinti csoportositás alapján megállapítható, hogy az 1891 és 1903 közötti években megjelent tankönyvekben (Mangold, 1891, 1902; Szigethy, 1903; Márki, 1903) a leggyakoribb az „Európa” főkategória előfordulása, tehát e kötetekben a legtöbb az „Európa” főkategória tartalmi alkategóriái hívószavainak összszáma (44-51 db között) (lásd 1. ábra).

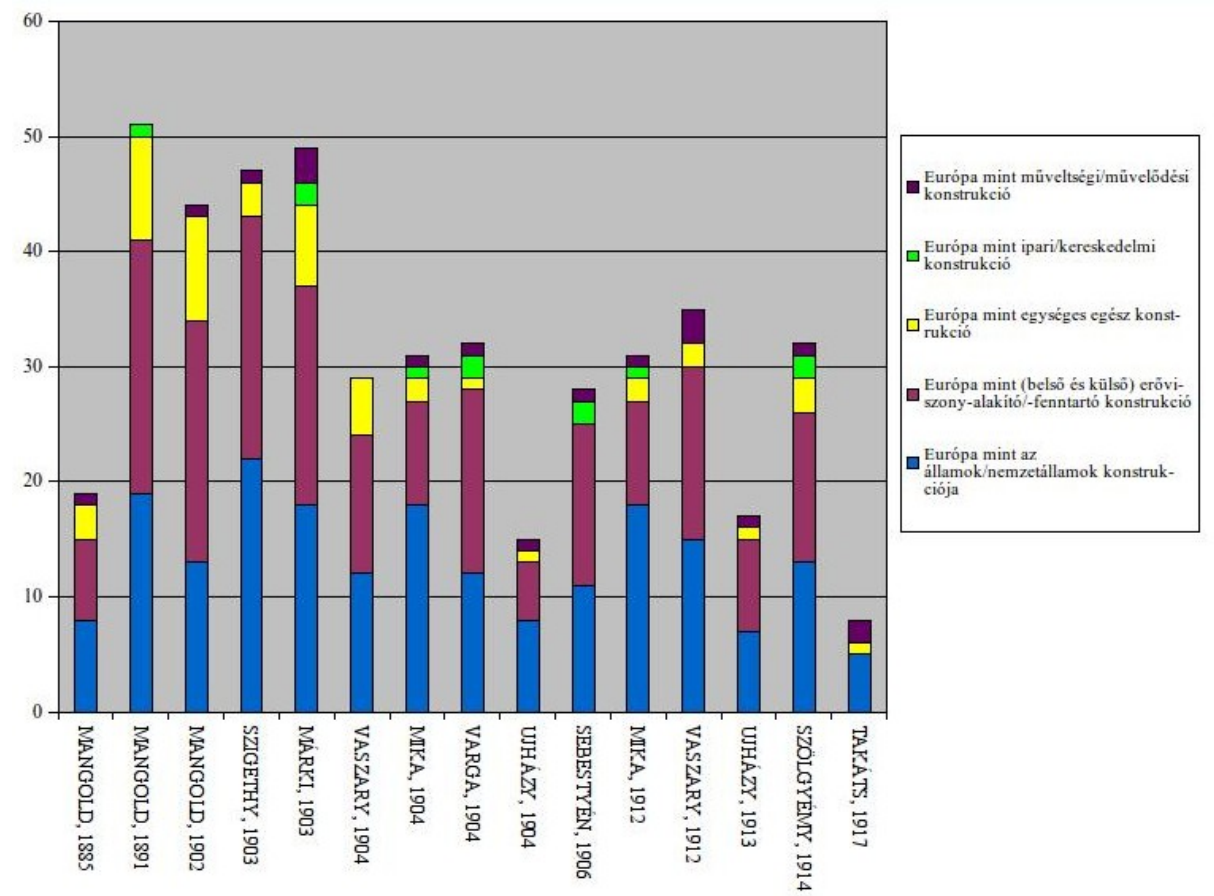

1. ábra. A tartalmi alkategóriák megoszlása tankönyvenként magyar kiadás éve szerinti csoportosításban) (db)

Ha az egyes alkategóriák reprezentációját közelebbről is megvizsgáljuk, akkor egyrészt - ahogy fentebb utaltunk rá - az „Európa mint a(z) (nemzet)államok konstrukciója” és az "Európa mint (belső és külső) erőviszony-alakitó és/vagy -fenntartó konstrukció" tartalmi alkategóriák dominanciája nyilvánvaló. Másrészt pedig szintén az 1891-1903 közötti években az „Európa mint egységes egész konstrukció" alkategória hívószavainak a száma érzékelhetően (de nem kiemelkedően) magasabb mint az azt követő dualizmus kori években. 
Pedagógiatörténeti Szemle • 2. évf. 1-2. sz. 40-60. o. • 2016 DOI:10.22309/PTSZEMLE.2016.1.3

További csoportosítási lehetőséget jelent a tartalmi alkategóriák megoszlására vonatkozó adatok szerzői ábécérend (azon belül pedig a kiadási évek) alapján történő kategorizálása.

A tartalomelemzés során 10 szerző összesen 15 db tankönyvére fókuszálunk. E kötetekből 4 szerző munkája emelhető ki, amelyek több kiadását is megvizsgáltuk: Mangold, 1885, 1891, 1902; Mika, 1904, 1912; Ujházy, 1904, 1913; Vaszary, 1904, 1912).

E tankönyveket áttekintve a kiadások előrehaladtával az „Európa” reprezentáció gyakorisága többnyire fokozódik, mindazonáltal a kötetektől (szerzőktől) függően ennek mértéke eltérő (lásd 2. ábra).

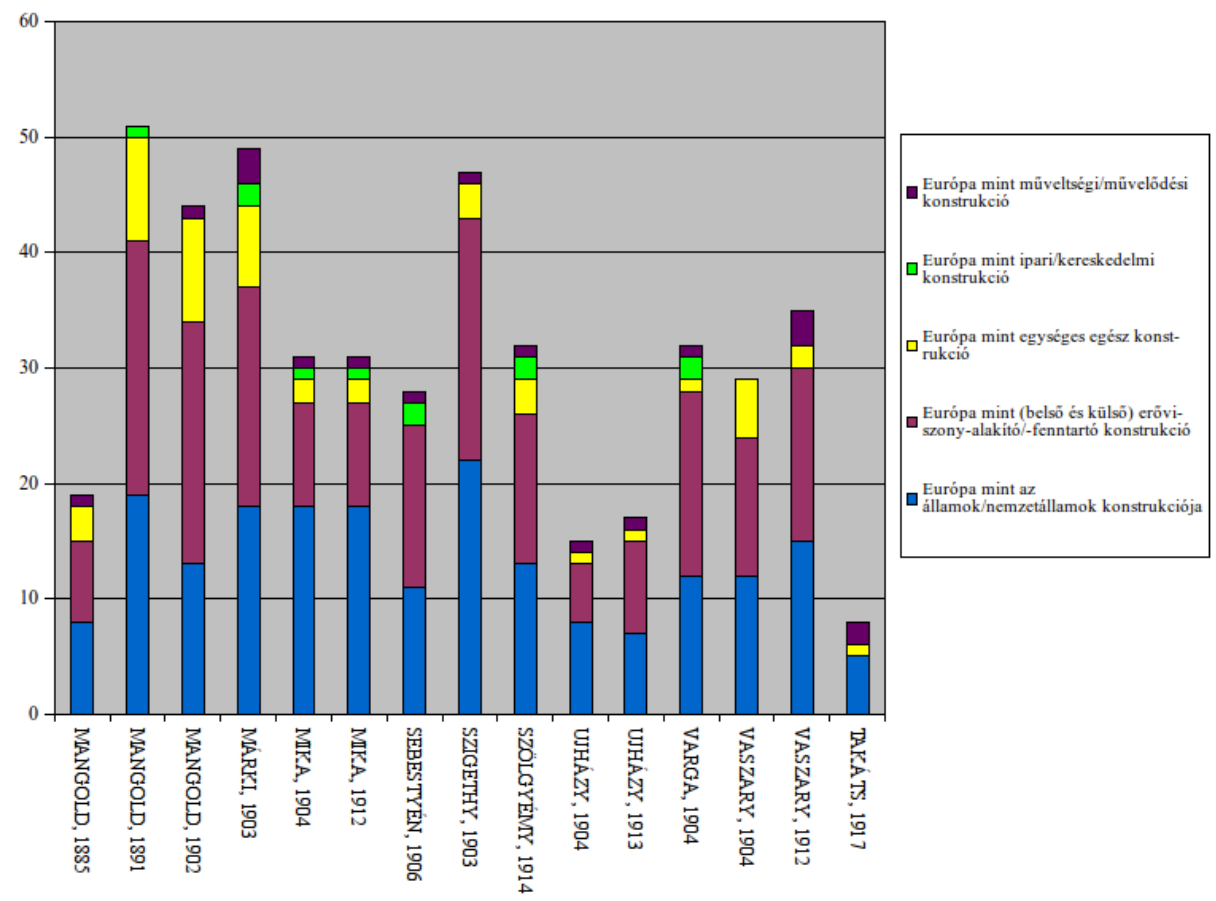

2. ábra. A tartalmi alkategóriák megoszlása tankönyvenként) (db)

A harmadik csoportosítási törekvés a hívószavak mennyisége szerint rendezi növekvő sorrendbe a tankönyvekből nyert adatokat. A 3. ábra alapján látható, hogy a kiadás éve (időrend) és a hívószavak mennyisége között nem áll fent releváns összefüggés. Mindazonáltal a diagram arra is rávilágít, hogy valamennyi vizsgált tankönyvi egységben az egyes tartalmi alkategóriák egymáshoz viszonyított aránya - figyelembe véve a változó hívószó bázis mennyiségét - körülbelül azonos (lásd az 1815 utáni tankönyvi fejezetek, alfejezetek tartalomelemzésének 6. lépése: A hívószavakra építve a tartalmi alkategóriák vizsgálata, 4 . bekezdés). 


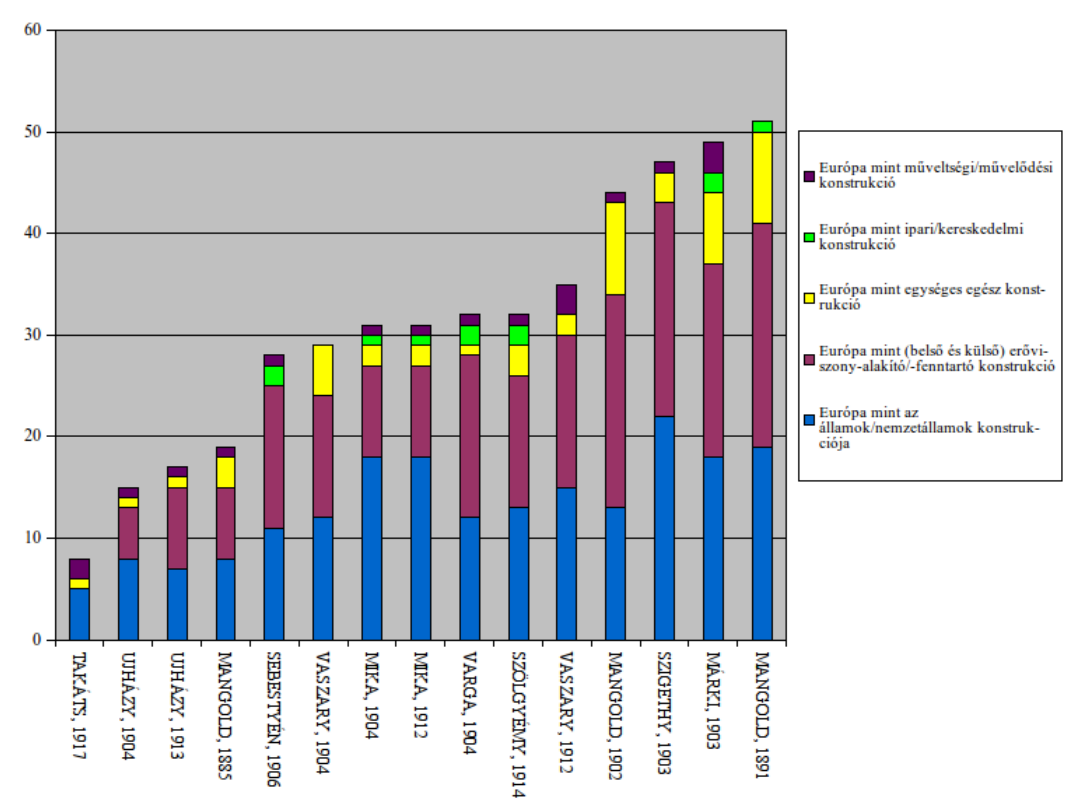

3. ábra. A tartalmi alkategóriák megoszlása tankönyvenként (hivószavak száma szerinti csoportosításban) (db)

A tankönyvenkénti bontás mellett a hívószavak számát a tartalmi alkategóriák mentén, a teljes vizsgálati minta szintjén is szükséges összesíteni. A 468 db hívószó 42,5 \%-a (199 db hívószó) az „Európa mint az államok/nemzetállamok konstrukciója”, 40,8%-a (191 db hívószó) pedig az „Európa mint (belsó és külső) erőviszony-alakító/-fenntartó konstrukció" alkategóriát képviseli. E két (nagy) alkategória tehát a 468 db hívószó 83,3 \%-át reprezentálja. Az „Európa mint egységes egész konstrukció” 10,5 \%-ot (49 db), az „Európa mint müveltségi/müvelődési konstrukció" 3,8 \%-ot (18 db hívószó), míg az „Európa mint ipari/kereskedelmi konstrukció" alkategória 2,4 \%-ot (11 db) tesz ki.

Emellett érdemes egy pillantást vetni az egyes alkategóriák leggyakoribb, illetve legnagyobb számban előforduló hívószavaira is. Az "Európa mint az államok/nemzetállamok konstrukciója" tartalmi alkategória rendelkezik a legnagyobb számban előforduló hívószavakkal. Ezek közt találjuk a "(nagy)hatalmak” (48 db), az "államok" (31 db) és a "nemzetek/népek” (24 db) hívószavakat.

Tankönyvi példák (idézetek) a „(nagy)hatalmak”, az „államok” és a "nemzetek/népek" hívószavakhoz:

(nagy)hatalmak:

„De bámulatosan fejlődött az új német császárság is, mely teljesen nemzeti alapon alakúlt meg s néhány év alatt Európa vezető hatalmassága lett." (Márki, 1903. 163-164. о.). 
„Orosz-török háború 1828-29. E pillanatban a görög forradalmat a bukástól az európai hatalmak közbelépése mentette meg. [...] Midőn Mohamed szultán az európai hatalmak közbelépését visszautasította, az egyesült angol, francia és orosz hajóhadak a török hajóhadat a Navarinnál vívott ütközetben megsemmisítették (1827)." (Mika, 1904. 130-131. o.).

államok:

„Az 1870-71. évi német háború a francziák ellen. [... ] Mialatt a legtöbb európai állam a francziák diadalát biztosra vette, kik maguk is az egész hadjáratot Berlin-be teendő sétának nevezték, egyszerre csak a harcztérről ellenkező hírek érkeztek, melyekből kitûnt, hogy a három német hadtest megtámadta a késedelmező francziákat és egyrészt Saarbrücken, másrészt Weiszenburg és Wörth-nél visszaszorította azokat, mely utóbbi két csatában a porosz trónörökös vezérlete alatt küzdő bajorok verték vissza Mac Mahon csapatjait. (1870. augusztus 2-6.)" (Mangold, 1891. 262. o.).

„1867-ben Ausztria is alkotmányt kapott. Igy tehát a hetvenes évek körül a legtöbb európai államban diadalra jutott a liberalismus." (Vaszary, 1912. 152. o.). nemzetek/népek:

„A februári forradalom hatása Olasz- és Németországban. Első kisérletek a nemzeti egyesúlésre. - A júliusi forradalom nagy reményeket ébresztett az európai népekben, de Belgium kivételével mindenütt a reakció felülkerekedése járt a nyomukban. Oroszország kegyetlen csapással mindenkorra véget vetett a lengyel szabadságnak, s ameddig Ausztria hatalma ért az olasz félszigeten és a német birodalomban, Metternich útját állta a népek törekvéseinek." (Sebestyén, 1906. 195. o.).

„Nemzeti államok alakulása. A krimiai háború. Az ötvenes évek reakciója visszazökkentette az európai népek közéletét a forradalom előtt fönnállott viszonyok közé. A belső mozgalmak egyelőre elültek s a közfigyelem a külső politika felé fordult, melyben a krimiai háború foglalkoztatta a hatalmakat." (Ujházy, 1913. 156. o.)

Szintén kiemelkedik a sorból az „Európa mint egységes egész konstrukció” tartalmi alka-tegória „egész/egység” (31 db), valamint az „Európa mint (belső és külső) erőviszony-alakító/-fenntartó konstrukció" ",béke” (19db) hívószava.

Tankönyvi példák (idézetek) az „egész/egység” és a „béke” hívószavakhoz: egész/egység:

„Ekkép történt, hogy az elmaradt Oroszországot és Törökországot leszámítva, manapság egész Európában alkotmányos élet van és így a szabadelvú eszmék annyi küzdelem után is végre diadalt arattak." (Varga, 1904. 163. o.).

„A kormányok szervezkedése a régi alapon. Franciaországban. A szent szövetség értelmében Európa minden részében a legitimitás elvén kivúl az abszolut hatalmat is visszaállították és a forradalmi elemet üldözőbe vették." (Vaszary, 1904. 137. o.).

béke:

„Lajos Fülöp. 1830-1848. [... ] Lajos Fülöpnek az volt a legnagyobb gondja, hogy Európát békés szándékai felől megnyugtassa, bizalmatlanságát eloszlassa 
és elismertetését kivívja. Ennek fejében megtagadta a lengyelek segítését és megengedte, hogy Ausztria az itáliai forradalmakat elnyomhassa." (Ujházy, 1913. 143. o.).

„(A hármas szövetség.) Oroszország a berlini congressus határozatai miatt megneheztelt Németországra, s úgy látszott, hogy Franciaországgal szövetségre lép. Minthogy e két hatalomnak közeledése háborút idézhetett volna fel Németország ellenében, Németország szövetségre lépett Ausztria' és Magyarországgal (1879), mely hatalom szintén veszélyeztetve volt Oroszország részéről BoszniaHercegovina megszállása miatt. E szövetséghez később (1883) Olaszország is csatlakozott s ennek oka az volt, Olaszország ellensúlyozni akarta Franciaországot, mely ez időben szállotta meg az olaszoktól sûrûn lakott Tuniszt. Az így létesült hármas szövetség azóta éber szemmel ôrködik Európa békéjén." (Vaszary, 1912. 154. о.).

$\mathrm{Az}$ „Európa mint müveltségi/müvelödési konstrukció” alkategória önmagában nem bír magas számú hívószó bázissal (összesen 18 db hívószóval), ugyanakkor - az alkategórián belüli magas aránya miatt - kiemelkedik a többi közül a „müveltség" elnevezésú hívószava (8 db).

Tankönyvi példák (idézetek) a "müveltség” hívószóhoz:

müveltség:

„Angolország reformkorszaka. [...] Óriási gyarmatai voltak a föld minden részében s iparának fejlettségéhez foghatót a világtörténelem nem mutathatott fel. Anglia volt a múvelt Európa eszményképe, a hova minden államférfiú és közgazda tanúlni ment; pl. Széchenyi István gróf 27-szer járt ottan s nemzetét szóval és tettel buzdította az angol szorgalom követésére." (Márki, 1903. 144. o.).

„Magyarország átalakulása. Széchenyi István gróf. [...] Az átalakulás szorosan össze van forrva Széchenyi István gróf nevével, aki Magyarország hátramaradottságának s a nemzet életképességének fölismerése után a maga nagy ambiciójához és hatalmas tehetségéhez mért föladatnak tekintette, hogy Nyugat-Európa múveltségét és politikai szabadságát hazájába átültesse." (Ujházy, 1913. 136. о.).

$\mathrm{Az}$ „Európa mint ipari/kereskedelmi konstrukció” szintén kevés számú hívószóval rendelkezik (11 db), melyek közül azonban - számát és arányát tekintve - nem emelkedik ki egyik hívószó sem.

A teljes vizsgálati minta szintjén arra is igyekeztünk fényt deríteni, hogy a hívószavak közt találhatóak-e olyanok, melyek valamennyi tankönyvben (vagy csaknem mindben) legalább egy alkalommal szerepelnek. E tekintetben a hívószavak közül egyértelmúen az - „Európa mint az államok/nemzetállamok konstrukciója” tartalmi alkategóriához sorolt - „(nagy)hatalmak” hívószó kerül előtérbe, mely minden vizsgált tankönyvi egységben fellelhető. Két további hívószó: az „államok" és a "nemzetek/népek" egy-egy tankönyv kivételével (előbbi esetében: Ujházy, 1904; utóbbi esetében: Takáts, 1917) szintén megtalálható az elemzett kötetekben. E három hívószón felül két további hívószó, illetve egy ún. hívószócsoport megemlítése is szükséges, melyek nem reprezentálják ugyan a teljes mintát, de a vizsgált múvek $\frac{2}{3}$-ában (10 db tankönyvben) jelen vannak. E két 
hívószó a „béke", valamint az „egész/egység”. A hívószó-csoportot pedig a „vezeto pozíció" kérdésköre jelenti, mely a következő hívószavakat foglalja magában: "vezetô államférfi/miniszter", „vezetó államok/országok”, ,vezető hatalom”, „vezeto szerep/parancsoló állás".

\section{ÖSSZEGZÉS - A VIZSGÁlATI EREDMÉNYEK RÖGZÍTÉSE AZ „EURÓPA” MINT TARTALMI FŐKATEGÓRIÁRA VONATKOZÓAN}

Az „Európa-kép” tartalmi elemzése során a vizsgálati minta 1815 utáni fejezeteit, alfejezeteit vettük górcső alá, hogy lássuk, miként ábrázolták Európát, az európaiságot a dualizmus kori középiskolai történelemtankönyvek. A tartalmi főkategóriák (azon belül pedig kiemelten „Európa”), a tartalmi alkategóriák és a hívószavak hármas rendszere a tankönyvi „Európa-kép” többszintú, egymásra épülő, árnyalt elemzését tette lehetővé, mely kvantitatív és kvalitatív kutatási eredmények kibontakozásának egyaránt teret engedett.

A kutatás kvantitatív szempontból igazolta Európa történelmének tankönyvi dominanciáját, kvalitatív szempontból pedig közelebb kerültünk a dualizmus kori középiskolai történelemtankönyvek „Európa-kép”-ének konceptualizálásához, a tartalmi hangsúlyok azonosításához.

\section{A KUTATÁSI EREDMÉNYEK SZINTETIZÁLÁSA}

A vizsgált tankönyvekből és tankönyvi egységekből kibontakozó „Európa-kép”et több aspektusból is megközelítettük. Ennek során figyelmet fordítottunk egyrészt a tankönyvi arányok, másrészt a fogalmi keretek, harmadrészt pedig a hangsúlyváltozások feltárására.

E kérdéscsoport mentén a tankönyvekből kibontakozó „Európa-kép” az alábbiak szerint összegezhető:

Tankönyvi arányok:

- Egyértelmúen az Európa-centrikus tankönyvi (és tantervi) tartalom a jellemző.

Fogalmi keretek:

- Az Európa/európaiság fogalma definiálatlan; nem jelenik meg deklarált Európa-fogalom.

- A tartalomelemzés révén ugyanakkor a látens „tankönyvi európaiság” meghatározható. A vizsgált dualizmus kori egyetemes középiskolai történelemtankönyvek Európát elsősorban mint (nemzet)államok összességét ábrázolták, illetve eróviszony-alakító és -fenntartó szerepét hangsúlyozták. Európa mint a (nemzet)államok összessége mindenekelőtt a „(nagy)hatalmak”, az „államok”, valamint a „nemzetek/népek” összességeként értelmezhető, másrészt Európa mint erőviszony-alakító és -fenntartó konstrukció két fő pilléren: az „egység”-en és a „béké”-n nyugszik.

E megállapítások egyúttal az „Európa-kép”-et befolyásoló tankönyvi tartalmak állandó tendenciáinak is tekinthetők. 
Hangsúlyváltozások:

- Az „Európa-kép”-et befolyásoló tankönyvi tartalmak változásait tekintve a vizsgálat során markáns tendenciák nem tárultak fel, mindazonáltal néhány tartalmi jellemvonás körvonalazható.

- A századforduló körüli években az Európa-reprezentáció erősebb, mint a megelőző és következő években.

- Az 1891-1903 közötti években Európa globalitása szintén némileg hangsúlyosabb, mint a dualizmus későbbi tankönyveiben.

- Ugyanazon tankönyvi kötetek különböző kiadásaiban, a kiadások előrehaladtával az „Európa”-reprezentáció gyakorisága többnyire növekedett, mindazonáltal a kötetektől (szerzőktől) függően ennek mértéke eltérő volt.

\section{FELHASZNÁLT IRODALOM}

Adamikné Jászó Anna (szerk.) (1990): A magyar olvasástanítás története. Tankönyvkiadó, Budapest.

Antal László (1976): A tartalomelemzés alapjai. Magvető Kiadó, Budapest.

Babbie, E. R. (2008): A társadalomtudományi kutatás gyakorlata. 6., átdolgozott kiadás, Balassi Kiadó, Budapest.

Dárdai Ágnes (2002): A tankönyvkutatás alapjai. Dialóg Campus Kiadó, Budapest-Pécs.

Dombi Alice (2015): Zsinórmérték és útmutatás. Tankönyvek és tankönyvírók a 19. században Magyarországon. Universitas Szeged Kiadó, Szeged.

Domokos Zsuzsa (2002): Az európaiság fogalma történelem tanterveink, tankönyveink tükrében. In: Szabolcs Ottó (sorozatszerk.): Történelempedagógiai Füzetek 12. A Magyar Történelmi Társulat Tanári Tagozata és az ELTE BTK kiadványa, Budapest. 5-23.

Európa-kutatás. In: Szabolcs Ottó és Katona András (2006, összeáll.): Történelem tantárgy-pedagógiai olvasókönyv. Dokumentumok a történelemtanítás történetének és módszertanának tanulmányozásához. Nemzeti Tankönyvkiadó, Budapest. 571-581.

Farkas Mária (2008): Történelemtanítás a népiskolákban a dualizmus kori Magyarországon. Szemléletformálás és értékközvetítés tantervek, olvasó- és történelemkönyvek tükrében. Trezor Kiadó, Budapest.

Fischerné Dárdai Ágnes (2011): A tankönyvek európai dimenziója. In: Borsodi Csaba (sorozatszerk.): A keresztény Európától az Európai Unió magyar elnökségéig. A Történelemtanári Továbbképzés Kiskönyvtára LV. Magyar Történelmi Társulat Tanári Tagozata - Eötvös Loránd Tudományegyetem Bölcsészettudományi Kar, Budapest. 50-68.

Fischerné Dárdai Ágnes (2012): Mit jelent az európai dimenzió a tankönyvekben? In: Orsós Anna és Trendl Fanni (szerk.): Útjelzők. Ünnepi kötet pályatársak, kollégák, tanítványok neveléstudományi tanulmányaiból a 70 esztendős Forray R. Katalin tiszteletére. PTE BTK, Pécs. 92-99. 
Gróz Andrea (2005): Az eredményes pedagógus egy 19. századi tanítóképzés pedagógiai tankönyv tükrében. Neveléstörténet, 2. 3-4. sz. 199-204.

Gróz Andrea (2007): A pedagógus-gyermek kapcsolat alakulása a dualizmus korában, tanítóképzős pedagógiai szakkönyvek tükrében. Doktori (PhD) disszertáció. Eötvös Loránd Tudományegyetem Neveléstudományi Doktori Iskola, Budapest.

Horváth Szilvia (2009): Az európai identitás diskurzuselméleti kérdései. Politikatudományi Szemle, XVIII. 4. sz. 105-125.

Letöltés: http://www.poltudszemle.hu/szamok/2009_4szam/horvathsz2009-4.pdf 2015. július 9. 13:45

M. Császár Zsuzsa (2004): Európa-kép a magyar földrajzoktatásban. In: III. Magyar Politikai Földrajzi Konferencia. Az integrálódó Európa politikai földrajza. PTE TTK Földrajzi Intézet, Pécs. 80-83.

Méreg Martin (2015): Schultz Imre népiskolai reálolvasókönyvének didaktikai felépítése német nyelvú olvasókönyvek tükrében. In: Andl Helga és Molnár-Kovács Zsófia (szerk.): Iskola a társadalmi térben és időben V. PTE „Oktatás és Társadalom" Neveléstudományi Doktori Iskola, Pécs. 83-103.

Mészáros István (1991): Európaiság, magyarság régi tankönyveinkben. Új Pedagógiai Szemle, XLI. 4. sz. 10-14.

Mollat du Jourdin, M. (1996): Európa és a tenger. Európa születése. Atlantisz Könyvkiadó, Budapest.

Molnár-Kovács Zsófia (2014): Az „Európa-kép“-kutatás fókuszpontjai a magyar és nemzetközi tankönyvi szakirodalom tükrében. Történelemtanítás Online történelemdidaktikai folyóirat, (XLIX.) Új folyam V. 2-4. sz.

Letöltés: http:/ / www.folyoirat.tortenelemtanitas.hu/wp-content/uploads /2014/12/05_02_12_Molnar.pdf 2015. június 25. 12:26

Molnár-Kovács Zsófia (2016): A dualizmus kori magyar középiskolai egyetemes történelemtankönyvek és azok változatai. Történelemtanitás - Online történelemdidaktikai folyóirat, (LI.) Új folyam VII. 3-4. sz.

Letöltés: http:/ / www.folyoirat.tortenelemtanitas.hu/wp-content/uploads/ 2016/12/07_03_06_Molnar-Kovacs.pdf 2016. december 22. 10:20

Nóbik Attila (2010): Klasszikusok és kánonképzés a magyar neveléstörténeti tankönyvekben (1867-1956). Doktori (PhD) értekezés. Szegedi Tudományegyetem Neveléstudományi Doktori Iskola, Szeged.

Penke Olga (2000): Filozofikus világtörténetek és történetfilozófiák. Balassi Kiadó, Budapest.

Seewann, G. (2009): A Németországról alkotott kép Magyarországon a 20. század első felében. In: Hornyák Árpád és Vitári Zsolt (szerk.): A magyarságkép a közép-európai tankönyvekben a 20. században. Kutatási füzetek 14. Pécsi Tudományegyetem, Pécs. 99-110.

Szabolcs Éva (2004): Tartalomelemzés. In: Falus Iván (szerk.): Bevezetés a pedagógiai kutatás módszereibe. Múszaki Könyvkiadó, Budapest. 330-339. 


\section{TANKÖNYVEK}

Mangold Lajos (1885): Világtörténelem. Középtanodai használatra. Harmadik kötet. Újkor és legujabb kor. Második, az új tanterv alapján ujonnan kidolgozott kiadás, képekkel és térképekkel, Franklin-Társulat, Budapest.

Mangold Lajos (1891): Világtörténelem. Középiskolai használatra. Harmadik kötet: Újkor és legujabb kor. Harmadik kiadás, Franklin-Társulat, Budapest.

Mangold Lajos (1902): Világtörténelem. Középiskolai használatra. Harmadik kötet. Ujkor 1648 óta s a legujabb kor. Ötödik, az uj tanterv alapján átdolgozott kiadás, Franklin-Társulat, Budapest.

Márki Sándor (1903): Egyetemes történelem. Gymnasiumok és reáliskolák számára. III. rész. Az új-kor 1648-1871-ig. A VII. osztály részére. Singer és Wolfner, Budapest.

Mika Sándor (1904): Világtörténet. Az uj tanterv alapján a középiskolák felső osztályai számára. III. kötet. - Uj-kor és legujabb kor. Lampel Róbert (Wodianer F. és Fiai) cs. és kir. udv. könyvkereskedés kiadása, Budapest.

Mika Sándor (1912): Világtörténet. Az új tanterv alapján a középiskolák felső osztályai számára. III. kötet. Új-kor és legújabb kor. Második kiadás, Lampel R. Kk. (Wodianer F. és Fiai) R. T. Könyvkiadóvállalata, Budapest.

Sebestyén Gyula (1906): Egyetemes történet. A középiskolák felsőbb osztályai számára. III. kötet. Újkor (1648-1871). Franklin-Társulat, Budapest.

Szigethy Lajos (1903): Egyetemes történet. Az 1899-ik évi tanitási terv szerint középiskolák VII. osztálya számára. Harmadik rész. Új-kor (1648-tól). Singer és Wolfner, Budapest.

Szölgyémy János (1914): Világtörténet. Főtekintettel a magyar nemzet történetére 1648-1913-ig. Európa és Amerika nevezetesebb államainak földrajzával. III. rész. Az új tanterv értelmében átdolgozott harmadik kiadás, Lampel R. Kk. (Wodianer F. és Fiai) R. T. Könyvkiadóvállalata, Budapest.

Takáts György (1917): Történelem. Leányközépiskolák használatára. Az új tanításteronek megfelelöen leányközépiskolák (felső leányiskolák, leánygimnáziumok és felső kereskedelmi leányiskolák) III. osztálya számára. A középkor és újkor történetének vázlata a magyarok honfoglalásától napjainkig. Negyedik, lényegesen átdolgozott kiadás, Athenaeum Irodalmi és Nyomdai Részvénytársulat kiadása, Budapest.

Ujházy László (1904): Egyetemes történelem. Középiskolák felső osztályai számára. III. rész. A hetedik osztály részére. Szent-István-Társulat kiadása, Budapest.

Ujházy László (1913): Egyetemes történelem. Középiskolák felső osztályai számára. III. rész. A hetedik osztály részére. Második átdolgozott kiadás, Szent-IstvánTársulat kiadása, Budapest.

Varga Ottó (1904): Világtörténet. Tanterv és utasitások alapján a középiskolák számára. Harmadik kötet: Új-kor. Harmadik javitott kiadás, Franklin-Társulat, Budapest.

Vaszary Kolos (1904): Világtörténelem. Középiskolák számára. III. kötet. A legújabb miniszteri tantervhez alkalmazott hatodik kiadás, Lampel Róbert (Wodianer F. és Fiai) cs. és kir. udvari könyvkereskedés kiadása, Budapest. 
Pedagógiatörténeti Szemle • 2. évf. 1-2. sz. 40-60. o. • 2016

DOI:10.22309/PTSZEMLE.2016.1.3

Vaszary Kolos (1912): Világtörténelem. Középiskolák számára. III. kötet. Újkor (1648-1789.) és legújabb kor (1789-től napjainkig). (Átdolgozta és kiegészítette: Németh Ambrus). Hetedik kiadás, Lampel R. Kk. (Wodianer F. és Fiai) R. T. Könyvkiadóvállalata, Budapest. 